\title{
A novel gyrB gene mutation in fluoroquinolone resistant clinical isolates of Mycobacterium tuberculosis
}

\author{
Pooja Singh, Amita Jain*, Pratima Dixit, Shantanu Prakash, Indu Jaiswal, Vimala Venkatesh, Mastan Singh \\ From 2nd International Science Symposium on HIV and Infectious Diseases (HIV SCIENCE 2014) \\ Chennai, India. 30 January - 1 February 2014
}

\section{Introduction}

Fluoroquinolone (FQ) resistance in Mycobacterium tuberculosis can be conferred by mutations in gyrA or gyrB gene. Recent studies suggest that amino acid substitutions in $\operatorname{gyr} B$ gene may also play a crucial role in resistance, but genetic studies of these mutations in $M$. tuberculosis are lacking.

\section{Methods}

A total of 100 ofloxacin resistant (OFX r) and 100 OFX sensitive (OFX s) isolates of M.tuberculosis isolates were consecutively selected from routine TB laboratory during 2012-2013. All the isolates were screened for phenotypic OFX $\mathrm{r}(>2 \mu \mathrm{g} / \mathrm{ml})$ by $1 \%$ proportion method and tested for minimal inhibitory concentration by absolute concentration method. Quinolone resistance determining region (QRDR) of $g y r A$ and $g y r B$ genes of 320bp and $428 \mathrm{bp}$ respectively were amplified, sequenced and compared with M.tuberculosis H37Rv.

\section{Results}

Mutations in the $\operatorname{gyr} B$ gene were observed in 5 of the 100 OFX $\mathrm{r}$ isolates. The single nucleotide mutation sites were in codons 538, 500, 539 (in two isolates) and 592. In one isolate, a substitution at codon 592 (Pro592Ser) was found as novel mutation outside QRDR region of $\mathrm{gyr} B$ gene. Accession nos. of these isolates include; KF509920KF509922, KC880086 \& KC880101. All the isolates showing mutations in $\operatorname{gyr} B$ gene also had mutations in gyrA gene. Mutations in gyrA gene were observed in $79 \%$ OFX $\mathrm{r}$ isolates. No mutation was observed in $\operatorname{gyr} B$ gene of OFX $\mathrm{s}$ isolates.

\footnotetext{
* Correspondence: amita602002@yahoo.com

Department of Microbiology, King George's Medical University, Lucknow, UP,
} India
Submit your next manuscript to BioMed Central and take full advantage of:

- Convenient online submission

- Thorough peer review

- No space constraints or color figure charges

- Immediate publication on acceptance

- Inclusion in PubMed, CAS, Scopus and Google Scholar

- Research which is freely available for redistribution Submit your manuscript at
www.biomedcentral.com/submit C BioMed Central 